(c) American Dairy Science Association, 2005.

\title{
Corn Grain Endosperm Type and Brown Midrib 3 Corn Silage: Feeding Behavior and Milk Yield of Lactating Cows
}

\author{
C. C. Taylor and M. S. Allen \\ Department of Animal Science, Michigan State University, East Lansing 48824-1225
}

\begin{abstract}
Interactions of endosperm type of corn grain and the brown midrib 3 mutation ( $\mathrm{bm} 3$ ) in corn silage on feeding behavior, productivity, energy balance, and plasma metabolites of lactating dairy cows were evaluated. Eight ruminally and duodenally cannulated cows $(72 \pm 8 \mathrm{~d}$ in milk; mean \pm SD) were used in a duplicated $4 \times 4$ Latin square design experiment with a $2 \times 2$ factorial arrangement of treatments. Treatments were corn grain endosperm type (floury or vitreous), and corn silage type (bm3 or isogenic control). Diets contained 26\% neutral detergent fiber (NDF) and $30 \%$ starch. Floury endosperm grain decreased dry matter intake (DMI) $1.9 \mathrm{~kg} /$ $\mathrm{d}$ compared with vitreous grain when combined with control corn silage but did not affect DMI when combined with $b m 3$ corn silage. This interaction of treatments occurred because of changes in meal size; floury endosperm grain decreased meal size in control silage diets but increased meal size in bm3 corn silage diets. Ruminal pool sizes reflected DMI differences among diets, suggesting that ruminal fill was not the primary limitation on intake. Brown midrib 3 corn silage reduced rumination time per day and number of rumination bouts per day. Floury endosperm grain decreased $3.5 \%$ fat-corrected milk by $1.2 \mathrm{~kg} / \mathrm{d}$ when combined with control silage but increased $3.5 \%$ fat-corrected milk by $2.1 \mathrm{~kg} / \mathrm{d}$ when combined with $\mathrm{bm} 3$ corn silage. Starch and fiber digestibility interact to affect feeding behavior and milk production and production response to $\mathrm{bm} 3$ corn silage depends on the grain source that is fed.

(Key words: endosperm, brown midrib, feeding behavior)
\end{abstract}

Abbreviation key: bm3 = brown midrib 3 mutation, $\mathbf{i N D F}=$ indigestible NDF, $\mathbf{N E}_{\mathbf{M}}=$ net energy for maintenance, $\mathbf{p d N D F}=$ potentially digestible NDF.

\section{INTRODUCTION}

Energy intake often limits milk yield for high-producing dairy cattle, and strategies to maximize energy in-

Received September 8, 2004.

Accepted December 10, 2004.

Corresponding author: Michael S. Allen; e-mail: allenm@msu.edu. take are critical to maximize production. Although diets are often formulated based on nutrient concentration alone, an analysis of the literature indicated that forage NDF digestibility measured in vitro or in situ was positively related to feed intake and milk yield; a mean increase in NDF digestibility of 8.4 units across forage comparisons was associated with a $1.4-\mathrm{kg} / \mathrm{d}$ greater DMI, resulting in a $2.1-\mathrm{kg} / \mathrm{d}$ greater $4 \% \mathrm{FCM}$ yield (Oba and Allen, 1999). The brown midrib mutation decreases lignin content and increases in vitro NDF digestibility of forages (Cherney et al., 1991). Feeding brown midrib sorghum (Grant et al., 1995) and corn (Oba and Allen, 2000a) silages have improved DMI and milk production in dairy cows; increases in DMI are a result of changes in meal patterns (Oba and Allen, 2000a). Brown midrib corn silage can affect DMI by changing meal patterns but how brown midrib corn silage interacts with other dietary components to affect feeding behavior is unknown.

Variation in starch digestibility is often not considered in diet formulation but ruminal starch digestibility for a variety of feedstuffs ranged from 42 to $96 \%$ (Nocek and Tamminga, 1991). Starch digestibility is dependent on several factors, including grain type, processing methods, and physical characteristics of the grain. Starch granules in vitreous or flinty endosperm are surrounded by an insoluble protein matrix that resists digestion; in contrast, floury or opaque endosperm has a soluble protein matrix that is easily digested by ruminal microorganisms (Kotarski et al., 1992). Grain vitreousness is dependent on both hybrid and maturity (Philippeau and Michalet-Doreau, 1997) and is negatively correlated with in situ ruminal starch disappearance across hybrids (Philippeau et al., 1999a). Flint endosperm decreased ruminal starch digestibility 26 percentage units ( 34.8 vs. $60.8, P<0.001)$ compared with a dent genotype when fed to steers (Philippeau et al., 1999b).

Increased ruminal starch degradability has significantly depressed DMI in some experiments but not others (Allen, 2000). Feed intake is a function of both meal size and meal frequency, determined by satiety and hunger, respectively, so meal patterns are likely influenced by ruminal starch digestion. Diets high in rumi- 
nally degraded starch decreased DMI by decreasing meal size (Oba and Allen, 2003a), and linear addition of refined cornstarch to the diet linearly decreased meal length but tended to increase the number of meals consumed in a day (Krause et al., 2003). Because endosperm type can dramatically change ruminal starch digestibility, research is needed to specifically examine the effect of corn endosperm type on feeding behavior of lactating dairy cows.

Although meal patterns and DMI are affected by changes in ruminal starch and fiber digestibility, potential interactions between varying digestibility of fiber source and endosperm type of corn grain on intake and production of dairy cows have not been investigated. We hypothesized that highly fermentable grain with floury endosperm would have greater effect at reducing meal size and possibly DMI when combined with brown midrib 3 (bm3) corn silage than control silage. The objective of this experiment was to evaluate effects of the bm 3 mutation in corn silage and corn grain endosperm type on feeding behavior, DMI, milk yield, and energy balance of lactating dairy cows.

\section{MATERIALS AND METHODS}

This article is the second of 3 articles in a series from one experiment that evaluated effects of corn grain endosperm type and the $b m 3$ mutation in corn silage. This article discusses treatment effects on feeding behavior and milk production, and the companion articles focus on ruminal fermentation and microbial $\mathrm{N}$ efficiency (Taylor and Allen, 2005a) and site of digestion and ruminal kinetics (Taylor and Allen, 2005b). Experimental procedures were approved by the All University Committee on Animal Use and Care at Michigan State University.

\section{Cows and Treatments}

Eight multiparous Holstein cows (72 \pm 8 DIM; mean \pm SD) from the Michigan State University Dairy Cattle Teaching and Research Center were assigned randomly to treatment sequence within duplicate $4 \times 4$ Latin squares balanced for carryover effects. A $2 \times 2$ factorial arrangement of treatments was used with main effects of corn grain endosperm type (floury or vitreous) and bm3 mutation in corn silage (present or absent). Treatment periods were $21 \mathrm{~d}$, consisting of an 11-d diet adaptation period followed by $10 \mathrm{~d}$ of collection. Surgical preparation of ruminally and duodenally cannulated cows is reported in Taylor and Allen (2005b). At the beginning of the experiment, empty body weight (ruminal digesta removed) of cows was $531.8 \pm 43.9 \mathrm{~kg}$ (mean $\pm \mathrm{SD})$.
Two corn hybrids, 6208FQ and 657 (Cargill Hybrid Seeds, Minneapolis, MN), were planted for silage in the spring of 2001 at the Michigan State University Research Farm. The hybrids are isogenic except that Cargill 657 contains the $b m 3$ mutation. Harvesting conditions of both silages were reported previously (Taylor and Allen, 2005b). Nutrient compositions and physical characteristics of treatment corn silages used in the experiment are reported in Table 1 of Taylor and Allen (2005b).

Two corn hybrids varying in endosperm type (floury and vitreous) were planted for grain in the spring of 2001 at the Michigan State University Research Farm. The floury (SL53; Crow's Hybrid Corn Company, Kentland, IN) and vitreous (Z75W; Wilson Genetics, Harlan, IA) hybrids were selected based on their high and low in vitro starch digestibility, respectively. Harvesting conditions of both corn grains were reported previously (Taylor and Allen, 2005b). Vitreousness (\% of endosperm) for floury and vitreous corn grain was 3.0 and $67.2 \%$, respectively (Taylor and Allen, 2005b). Nutrient compositions and physical characteristics of the corn grain treatments used in the experiment are shown in Table 2 of Taylor and Allen (2005b).

Experimental diets contained dry ground corn treatments (floury or vitreous), corn silage (bm3 or isogenic normal), alfalfa silage ( $10 \%$ of diet DM), whole linted cottonseed (7\% of diet DM), a protein supplement premix (soybean meal, distillers grains, and blood meal), and a premix of minerals and vitamins. Experimental diets were fed as TMR and were formulated to contain $27 \% \mathrm{NDF}, 18 \% \mathrm{CP}$, and minerals and vitamins to meet requirements according to NRC (2001). Ingredient and nutrient compositions of the experimental diets are reported in Table 3 of Taylor and Allen (2005b).

\section{Data and Sample Collection}

Cows were housed and fed as described previously (Taylor and Allen, 2005b). Cows were milked twice daily in their stalls during the feeding behavior monitoring phase (d 15 to 18) and in a milking parlor during the remainder of each period. Milk yield was measured and milk was sampled at each milking on d 15 to 18. Empty body weight was measured after evacuation of ruminal digesta on the day immediately before the start of the first period and on d 21 of each period. Body condition score was determined on the same day by 3 trained investigators blinded to treatments (Wildman et al., 1982; 5-point scale where $1=$ thin and $5=$ fat).

Feeding behavior was monitored from d 15 through d $18(96 \mathrm{~h})$ of each period by a computerized data acquisition system (Dado and Allen, 1993). Data of chewing activities, feed disappearance, and water consumption 
were recorded for each cow every $5 \mathrm{~s}$. When chewing equipment malfunctioned for an individual cow during a 24-h period (1100 to $1100 \mathrm{~h}$ ), chewing behavior data were deleted for that cow during that 24 -h period. The system successfully collected $79.0 \%$ of the total chewing behavior data (average $3.1 \mathrm{~d} /$ cow per period).

Blood was collected from a coccygeal vessel into 2 evacuated tubes (Vacutainer, Becton Dickinson, Franklin Lakes, NJ), one containing sodium heparin and one containing potassium oxalate and sodium fluoride. Samples were collected every $9 \mathrm{~h}$ from d 12 to 14, starting at $1400 \mathrm{~h}$ on $\mathrm{d} 12$, so that samples represented 3 -h intervals of a $24-\mathrm{h}$ period to account for diurnal variation. Blood was centrifuged at $2000 \times g$ for 15 min immediately after sample collection; plasma was harvested and frozen at $-20^{\circ} \mathrm{C}$ until analysis.

Ruminal contents were evacuated manually through the ruminal cannula at $1500 \mathrm{~h}$ ( $4 \mathrm{~h}$ after feeding) on $\mathrm{d}$ 20 and at $0900 \mathrm{~h}$ ( $2 \mathrm{~h}$ before feeding) on $\mathrm{d} 21$ of each period. Total ruminal content mass and volume were determined. During evacuation, $10 \%$ aliquots of digesta were separated to allow accurate sampling. Aliquots were squeezed through a nylon screen (1-mm pore size) to separate into primarily solid and liquid phases. Samples were taken from both phases for determination of nutrient pool size and an additional liquid sample was taken to measure VFA concentration. All samples were frozen immediately at $-20^{\circ} \mathrm{C}$.

\section{Sample and Statistical Analyses}

Diet ingredients and orts were dried and ground as described in a companion article (Taylor and Allen, 2005b). Rumen liquid and solid subsamples were lyophilized (TriPhilizer MP, FTS Systems, Stone Ridge, NY), ground, and recombined according to the original ratio of solid and liquid DM. All dried samples were analyzed for DM, ash, NDF, indigestible NDF (iNDF), potentially digestible NDF (pdNDF; 1 - iNDF), CP, and starch as described in Taylor and Allen (2005b).

Commercial kits were used to determine plasma concentration of insulin (Coat-A-Count, Diagnostic Products Corp., Los Angeles, CA), pancreatic glucagon (Linco Research, Inc., St. Charles, MO), glucose (glucose kit \#510; Sigma Chemical Co., St. Louis, MO), NEFA (NEFA C-kit; Wako Chemicals USA, Richmond, VA), and $\beta$-hydroxybutyrate (procedure no. 2440; Stanbio Laboratory, Boerne, TX). Milk samples were analyzed for fat, true protein, and lactose with infrared spectroscopy, and for urea nitrogen by chemical methodology based on a modified Berthelot reaction (ChemSpec 150 Analyzer, Bentley Instruments, Chaska, MN) by Michigan DHIA (East Lansing).
For analysis of feeding and chewing behavior data, daily means were calculated for number of meal bouts per day, interval between meals, meal size, eating time, ruminating time, and total chewing time. Daily means for each response variable were averaged over the number of successful collection days for each period and for statistical analysis were weighted according to the number of successful collection days.

Energy values for $\mathrm{NE}_{\mathrm{L}}$ and net energy for maintenance $\left(\mathbf{N E}_{\mathbf{M}}\right)$ were calculated as follows:

$$
\begin{gathered}
\mathrm{NE}_{\mathrm{L}} \text { intake }(\mathrm{Mcal} / \mathrm{d})=\mathrm{DMI}(\mathrm{kg}) \times(0.0245 \\
\times \mathrm{TDN} \%)(\mathrm{NRC}, 1989)
\end{gathered}
$$

DM digestibility (for TDN \% calculation) reported in Taylor and Allen (2005b);

$$
\begin{aligned}
\text { Milk } \mathrm{NE}_{\mathrm{L}} & (\mathrm{Mcal} / \mathrm{kg})=0.0929 \times(\text { Fat \% })+0.0563 \\
& \times(\text { True Protein \% })+0.0395 \\
& \times(\text { Lactose \% }(\mathrm{NRC}, 2001)
\end{aligned}
$$

$$
\begin{aligned}
& \mathrm{NE}_{\mathrm{M}}(\mathrm{Mcal} / \mathrm{d})= 0.080 \times \mathrm{BW}^{0.75}(\mathrm{NRC}, 2001) ; \text { and } \\
& \mathrm{NE}_{\mathrm{L}} \text { balance }(\mathrm{Mcal} / \mathrm{d})=\mathrm{NE}_{\mathrm{L}} \text { intake }-\mathrm{NE}_{\mathrm{M}} \\
&-\mathrm{NE}_{\mathrm{L}}(\mathrm{Mcal} / \mathrm{d}) .
\end{aligned}
$$

Ruminal pool sizes (kg) of OM, NDF, iNDF, and starch were determined by multiplying the concentration of each component in DM by the ruminal digesta DM weight $(\mathrm{kg})$.

All data were analyzed using the fit model procedure of JMP (Version 4, SAS Institute, Cary, NC) according to the following model:

$$
\mathrm{Y}_{\mathrm{ijk}}=\mu+\mathrm{C}_{\mathrm{i}}+\mathrm{P}_{\mathrm{j}}+\mathrm{T}_{\mathrm{k}}+\mathrm{PT}_{\mathrm{jk}}+\mathrm{e}_{\mathrm{ijk}}
$$

where $\mu$ = overall mean, $\mathrm{C}_{\mathrm{i}}=$ random effect of cow $(\mathrm{i}=$ 1 to 8$), P_{j}=$ fixed effect of period ( $\mathrm{j}=1$ to 4$), \mathrm{T}_{\mathrm{k}}=$ fixed effect of treatment ( $\mathrm{k}=1$ to 4$), \mathrm{PT}_{\mathrm{jk}}=$ interaction of period and treatment, and $\mathrm{e}_{\mathrm{ijk}}=$ residual.

A reduced model without period $\times$ treatment interactions was used when this effect was not significant $(P$ $>0.15)$. Orthogonal contrasts were used to determine main effect of corn silage type, main effect of corn grain type, and the interaction of corn silage type and endosperm type of corn grain. Pearson correlation coefficients were determined between cow-period observations for some parameters. Main treatment effects and correlations were declared significant at $P<0.05$ and tendencies were declared at $P<0.10$. Interactions between treatments were declared significant at $P<0.10$ and tendencies were declared at $P<0.15$.

Data for one cow were removed from all statistical analysis due to clinical mastitis during the first period. 
Table 1. Effects of corn grain endosperm type and brown midrib 3 corn silage on feeding behavior.

\begin{tabular}{|c|c|c|c|c|c|c|c|c|}
\hline & \multicolumn{2}{|c|}{ Control } & \multicolumn{2}{|c|}{$b m 3$} & \multirow[b]{2}{*}{ SEM } & \multicolumn{3}{|c|}{$P$} \\
\hline & Floury & Vitreous & Floury & Vitreous & & $\mathrm{S}^{1}$ & $\mathrm{G}^{2}$ & $\mathrm{~S} \times \mathrm{G}^{3}$ \\
\hline DMI, kg/d & 23.6 & 25.5 & 25.2 & 24.9 & 1.0 & 0.40 & 0.18 & 0.07 \\
\hline Meal bouts, no./d & 10.8 & 10.4 & 11.2 & 12.1 & 0.8 & 0.10 & 0.74 & 0.31 \\
\hline Meal length, min & 28.0 & 28.4 & 27.0 & 24.0 & 1.3 & 0.02 & 0.23 & 0.12 \\
\hline DM meal size, $\mathrm{kg}$ & 2.18 & 2.47 & 2.25 & 2.05 & 0.13 & 0.11 & 0.67 & 0.03 \\
\hline Intermeal interval, min & 95.5 & 98.0 & 90.3 & 93.1 & 6.9 & 0.32 & 0.59 & 0.97 \\
\hline
\end{tabular}

${ }^{1}$ Main effect of corn silage hybrid.

${ }^{2}$ Main effect of ground corn grain endosperm type.

${ }^{3}$ Interaction of corn silage hybrid and ground corn grain endosperm type.

This cow was replaced with a spare animal for the remaining 3 periods. Another cow developed pneumonia during the diet adaptation subperiod of period 2 and was recovering during the first day of the collection period. Data for this cow were omitted from the digestibility subperiod of period 2 but were used from the feeding behavior subperiod as it had recovered sufficiently.

\section{RESULTS AND DISCUSSION}

\section{DMI and Meal Patterns}

A significant interaction of main effects was detected for DMI $(P<0.07$; Table 1$)$. Specifically, endosperm type had no effect on DMI within bm3 corn silage diets, but floury endosperm grain decreased intake by 1.9 $\mathrm{kg} / \mathrm{d}$ compared with vitreous grain within control corn silage diets. This interaction of treatments was caused by changes in meal intake patterns; floury endosperm grain decreased DM meal size by $0.29 \mathrm{~kg}$ compared with vitreous corn grain when combined with control corn silage, but had the opposite effect (increasing DM meal size $0.20 \mathrm{~kg}$ compared with vitreous grain) for diets containing $b m 3$ corn silage. Diets containing vitreous corn grain and $b m 3$ silage did not reduce DMI despite a smaller meal size because cows consuming $b m 3$ silage tended to eat a greater number of meals per day (10.6 vs. $11.7, P<0.10)$. Control of meal size and frequency can be affected by numerous factors related to physical distension, metabolism of fuels, or hormonal effects. Because diets were relatively low in NDF and ruminal pool size responded in a similar fashion to DMI, physical factors were probably not limiting DMI. Therefore, the focus of this discussion will be on metabolic and hormonal factors limiting DMI.

Increased ruminal starch degradability has been shown to decrease DMI in some but not all cases (Allen, 2000). Inconsistent effects of ruminal starch fermentation on DMI might be the result of temporal pattern of fuel supply relative to the rate of use for milk yield and body tissues. Hypophagic effects of propionate are well documented and the mechanism might be related to its oxidation in the liver (Allen, 2000). Oxidation of a variety of metabolic fuels in the liver has been shown to depress feed intake for nonruminants (Langhans, 1996). Infusions of propionate into the rumen linearly decreased DMI and meal size in lactating cows, and extent of hypophagia induced by propionate infusion was positively related to plasma glucose concentration (Oba and Allen, 2003b). Oba and Allen (2003b) speculated that propionate from rapid ruminal fermentation is oxidized in the liver, causing satiety in animals when flux to the liver exceeds its flux through the gluconeogenic pathway. Increased glucose demand as milk yield increases creates a draw for metabolites to be used for gluconeogenesis rather than oxidation and might reduce the hypophagic effects of propionate. In support of this, plasma glucose was negatively correlated with DM meal size across cow period means $(\mathrm{r}=-0.37 ; P<$ 0.04 ) in the present experiment. Oxidation of metabolic fuels may explain the interaction of treatments observed for meal size. Floury endosperm increased ruminal propionate concentration $(P<0.001$; Taylor and Allen, 2005a) and more rapid fermentation of starch from floury endosperm grain (Taylor and Allen, 2005b) likely increased absorption of propionate and other VFA during meals compared with vitreous endosperm corn grain. Because milk production (and glucose demand) was not increased in diets containing floury corn grain and control corn silage, these metabolic fuels might have been oxidized in the liver, thus reducing meal size. Conversely, in floury corn grain and bm3 corn silage diets, milk production and glucose demand were increased and fuels were likely directed toward gluconeogenesis, thus reducing oxidation of fuels and increasing meal size.

Although vitreous grain with $b m 3$ silage reduced DM meal size, meal frequency tended to increase to compensate. Oba and Allen (2000a) reported that cows consuming $b m 3$ corn silage ate smaller meals more frequently 
Table 2. Effects of corn grain endosperm type and brown midrib 3 corn silage on chewing behavior.

\begin{tabular}{|c|c|c|c|c|c|c|c|c|}
\hline & \multicolumn{2}{|c|}{ Control } & \multicolumn{2}{|c|}{$b m 3$} & \multirow[b]{2}{*}{ SEM } & \multicolumn{3}{|c|}{$P$} \\
\hline & Floury & Vitreous & Floury & Vitreous & & $\mathrm{S}^{1}$ & $\mathrm{G}^{2}$ & $\mathrm{~S} \times \mathrm{G}^{3}$ \\
\hline \multicolumn{9}{|l|}{ Chewing time, $\mathrm{min} / \mathrm{d}$} \\
\hline Total & 755 & 745 & 728 & 680 & 20.3 & 0.001 & 0.02 & 0.12 \\
\hline Eating & 259 & 258 & 266 & 242 & 6.4 & 0.36 & 0.02 & 0.03 \\
\hline Ruminating & 496 & 486 & 462 & 438 & 20.9 & 0.002 & 0.16 & 0.53 \\
\hline \multicolumn{9}{|l|}{ Total chews } \\
\hline$/ \mathrm{kg}$ of DMI & 2241 & 2006 & 1984 & 1961 & 95 & 0.002 & 0.005 & 0.02 \\
\hline$/ \mathrm{d}$ & 50,796 & 50,432 & 48,316 & 45,649 & 1446 & 0.002 & 0.15 & 0.26 \\
\hline \multicolumn{9}{|l|}{ Eating chews } \\
\hline /meal & 1907 & 1958 & 1828 & 1650 & 111 & 0.08 & 0.56 & 0.30 \\
\hline /kg of DMI & 880 & 802 & 816 & 801 & 44 & 0.14 & 0.05 & 0.16 \\
\hline$/ \mathrm{d}$ & 19,939 & 19,886 & 19,966 & 18,660 & 782 & 0.30 & 0.25 & 0.28 \\
\hline \multicolumn{9}{|l|}{ Ruminating chews } \\
\hline /bout & 2218 & 2073 & 1988 & 1945 & 177 & 0.03 & 0.23 & 0.51 \\
\hline /kg of DMI & 1361 & 1204 & 1168 & 1160 & 84 & 0.006 & 0.04 & 0.06 \\
\hline$/ \mathrm{d}$ & 30,854 & 30,375 & 28,344 & 26,981 & 1584 & 0.001 & 0.25 & 0.57 \\
\hline \multicolumn{9}{|l|}{ Ruminating } \\
\hline Bouts, no./d & 14.3 & 14.9 & 14.5 & 14.3 & 0.6 & 0.62 & 0.63 & 0.28 \\
\hline Bout length, min & 36.1 & 33.4 & 32.8 & 32.0 & 2.5 & 0.03 & 0.11 & 0.39 \\
\hline Interval, $\min$ & 65.2 & 62.1 & 63.4 & 62.1 & 2.9 & 0.74 & 0.40 & 0.74 \\
\hline Water intake, L/d & 94.4 & 90.5 & 92.9 & 92.0 & 4.2 & 0.99 & 0.33 & 0.53 \\
\hline
\end{tabular}

when compared with control corn silage in low (29\%) NDF diets and speculated that more rapid VFA absorption decreased meal size but increased rate of VFA utilization, which resulted in hunger sooner and increased feeding frequency. In diets containing vitreous corn grain, greater oxidation of fuels within meals with $\mathrm{bm} 3$ vs. control corn silage might explain the smaller meal size. Although valerate absorption rate (a measure of VFA absorption rate) was not different among treatments, propionate concentration of rumen fluid was numerically higher and acetate:propionate ratio and ruminal $\mathrm{pH}$ were numerically lower in vitreous grain diets containing $b m 3$ vs. control silage (Taylor and Allen, 2005a), consistent with greater propionate production. Additionally, plasma insulin:glucagon ratio tended to be higher for vitreous grain $(P<0.07)$, primarily because the diet containing vitreous corn grain and bm3 silage increased plasma insulin and reduced glucagon concentrations compared with other treatments. Higher plasma insulin:glucagon ratio is expected to result in increased oxidation of fuels in the liver (Watford and Goodridge, 2000), contributing to satiety. Hepatic oxidation of fuels varies over time and a reduction in meal size can be compensated for by an increase in meal frequency, which occurred for diets containing vitreous corn grain and $b m 3$ corn silage.

In addition to oxidation of metabolic fuels, gut peptides could have influenced meal patterns because of the significant changes in site of starch digestion (Tay- lor and Allen, 2005b). Intraduodenal glucose infusion strongly elicited increases in plasma insulin, glucosedependent insulinotropic polypeptide, and glucagonlike peptide-1 in humans (Lavin et al., 1998). Although glucose-dependent insulinotropic polypeptide and glucagon-like peptide-1 appear to play a role in signaling satiety (Havel, 2001), this has not been definitively established and little work has been conducted on the role of gut peptides in regulation of DMI for ruminants.

\section{Chewing Activity}

Chewing time (total and eating) was similar between endosperm types in control corn silage diets but floury endosperm grain tended to increase chewing time (total and eating) vs. vitreous grain in $\mathrm{bm} 3$ silage diets (interaction $P<0.12$ and $P<0.03$, respectively; Table 2 ). These interactions occurred because of the interaction of main treatment effects for DMI and for chewing per kilogram of DMI. Both floury corn grain and control silage increased chewing per kilogram of DMI but floury corn grain increased chewing to a greater extent when combined with control than with $b m 3$ corn silage. Although rate of starch digestion was highest in this diet (Taylor and Allen, 2005b), cause and effect is not apparent. Ruminating time per day was positively related to rate of starch digestion across cow period means $(r=$ $0.37 ; P<0.05)$. Greater mastication increased starch digestion rate of several cereals (Beauchemin et al., 
Table 3. Effects of corn grain endosperm type and brown midrib 3 corn silage on ruminal pools.

\begin{tabular}{|c|c|c|c|c|c|c|c|c|}
\hline & \multicolumn{2}{|c|}{ Control } & \multicolumn{2}{|c|}{$b m 3$} & \multirow[b]{2}{*}{ SEM } & \multicolumn{3}{|c|}{$P$} \\
\hline & Floury & Vitreous & Floury & Vitreous & & $S^{1}$ & $\mathrm{G}^{2}$ & $\mathrm{~S} \times \mathrm{G}^{3}$ \\
\hline Wet weight, $\mathrm{kg}$ & 75.0 & 83.0 & 74.9 & 76.4 & 3.7 & 0.27 & 0.12 & 0.28 \\
\hline Volume, L & 89.1 & 96.9 & 87.3 & 90.0 & 4.9 & 0.28 & 0.20 & 0.53 \\
\hline Density, kg/L & 0.85 & 0.86 & 0.84 & 0.85 & 0.02 & 0.58 & 0.54 & 0.93 \\
\hline \multicolumn{9}{|l|}{ Rumen pool, kg } \\
\hline $\mathrm{DM}$ & 10.2 & 12.3 & 11.6 & 10.9 & 0.68 & 0.95 & 0.20 & 0.02 \\
\hline $\mathrm{OM}$ & 9.37 & 11.18 & 10.62 & 9.92 & 0.66 & 0.99 & 0.29 & 0.03 \\
\hline $\mathrm{NDF}$ & 5.41 & 6.34 & 5.95 & 5.37 & 0.43 & 0.49 & 0.59 & 0.03 \\
\hline $\mathrm{pdNDF}^{4}$ & 2.75 & 3.16 & 3.75 & 3.44 & 0.27 & 0.004 & 0.78 & 0.08 \\
\hline $\mathrm{iNDF}^{5}$ & 2.67 & 3.18 & 2.20 & 1.93 & 0.19 & $<0.0001$ & 0.42 & 0.02 \\
\hline Starch & 0.74 & 0.95 & 0.89 & 0.98 & 0.08 & 0.24 & 0.07 & 0.42 \\
\hline
\end{tabular}

${ }^{1}$ Main effect of corn silage hybrid.

${ }^{2}$ Main effect of ground corn grain endosperm type.

${ }^{3}$ Interaction of corn silage hybrid and ground corn grain endosperm type.

${ }^{4} \mathrm{pdNDF}=$ Potentially digestible NDF.

${ }^{5} \mathrm{iNDF}=$ Indigestible NDF.

1994) and rate of starch digestion increases as corn particle size decreases (Callison et al., 2001). Greatest rate of starch digestion in the diet containing floury endosperm grain and control silage could be related to greater chewing per kilogram of DMI; however, the cause of greater chewing is unknown.

Total ruminating time per day, rumination bout length, and ruminating chews per bout and per day were greater for diets containing control vs. $b m 3$ corn silage (Table 2). These results suggest that $b m 3$ silage may not be as effective as control corn silage in stimulating rumination. In contrast, Oba and Allen (2000b) reported that ruminating time per day was not different between $b m 3$ and control corn silages and concluded that $b m 3$ corn silage was as effective as normal corn silage in stimulating chewing activity. Similar to results in the current experiment, brown midrib sorghum silage tended to decrease chewing per kilogram of NDF intake when compared with normal sorghum silage (Grant et al., 1995). Enhanced fiber degradability and increased particle fragility of brown midrib hybrids could cause brown midrib silages to be slightly less effective at stimulating chewing than normal corn silages. Differences in the ability of $b m 3$ corn silage to stimulate chewing compared with control corn silage between the current experiment and that of Oba and Allen (2000b) might be because of differences in environmental and management effects on the in vitro NDF digestibility of the hybrids; 30 -h in vitro NDF digestibility of the $b m 3$ hybrid used in this experiment was greater than the bm 3 hybrid used in the experiment by Oba and Allen (2000a). Corn hybrids with the $b m 3$ mutation might be a less effective fiber source compared with normal corn silage and might require higher minimum forage NDF concentrations in diets.

\section{Ruminal Nutrient Pools}

Significant interactions of main treatment effects were detected for ruminal pools of $\mathrm{DM}(P<0.03)$ and $\mathrm{OM}$ $(P<0.03$; Table 3$)$. Similar to DMI, floury endosperm decreased DM and OM pool size when combined with control silage but increased pool sizes when in bm3 silage diets. Significant interactions of treatments for ruminal pools of NDF $(P<0.03)$, pdNDF $(P<0.08)$, and iNDF $(P<0.02)$ were also detected. These pools reflected DMI differences among diets but also indicated greater pool size of pdNDF and smaller iNDF pool size in diets containing $b m 3$ silage. The ability of the pool size to reflect changes in DMI indicated that intake was not likely limited by ruminal fill in these animals. Starch ruminal pool size tended $(P<0.07)$ to be greater for vitreous vs. floury corn grain because ruminal turnover rate of starch was numerically greater for floury vs. vitreous corn grain (Taylor and Allen, 2005b). Wet weight, volume, and density of ruminal contents did not differ among treatments.

\section{Milk Yield and Composition}

In control corn silage diets, floury corn grain decreased $3.5 \%$ FCM by $1.2 \mathrm{~kg} / \mathrm{d}$, but increased FCM by $2.1 \mathrm{~kg} / \mathrm{d}$ when combined with $b m 3$ corn silage $(P<0.10$; Table 4). A similar trend occurred for milk yield ( $P$ $<0.22)$ and milk fat percentage $(P<0.11)$. Milk fat percentage was similar between diets containing floury grain regardless of silage type, but compared with floury grain, corn grain with vitreous endosperm tended to increase milk fat percentage in control silage diets but not in $b m 3$ silage diets. Milk fat percentage was positively correlated with ruminal $\mathrm{pH}(\mathrm{r}=0.58 ; P<$ 
Table 4. Effects of corn grain endosperm type and brown midrib 3 corn silage on milk yield and components.

\begin{tabular}{|c|c|c|c|c|c|c|c|c|}
\hline & \multicolumn{2}{|c|}{ Control } & \multicolumn{2}{|c|}{$b m 3$} & \multirow[b]{2}{*}{ SEM } & \multicolumn{3}{|c|}{$P$} \\
\hline & Floury & Vitreous & Floury & Vitreous & & $S^{1}$ & $\mathrm{G}^{2}$ & $\mathrm{~S} \times \mathrm{G}^{3}$ \\
\hline \multicolumn{9}{|l|}{ Yield, kg/d } \\
\hline Raw milk ${ }^{4}$ & 39.8 & 40.6 & 42.5 & 40.6 & 2.1 & 0.21 & 0.59 & 0.22 \\
\hline $3.5 \% \mathrm{FCM}$ & 39.7 & 40.9 & 42.2 & 40.1 & 2.2 & 0.40 & 0.62 & 0.10 \\
\hline Fat & 1.40 & 1.45 & 1.48 & 1.40 & 0.09 & 0.69 & 0.69 & 0.07 \\
\hline Protein & 1.18 & 1.20 & 1.28 & 1.19 & 0.07 & 0.28 & 0.44 & 0.19 \\
\hline Lactose & 1.95 & 1.99 & 2.09 & 1.98 & 0.11 & 0.22 & 0.58 & 0.20 \\
\hline SNF & 3.50 & 3.57 & 3.78 & 3.56 & 0.19 & 0.23 & 0.52 & 0.21 \\
\hline MUN, mg/dL & 16.5 & 16.6 & 15.0 & 15.8 & 0.58 & 0.005 & 0.24 & 0.29 \\
\hline \multicolumn{9}{|l|}{ Composition, \% } \\
\hline Fat & 3.51 & 3.62 & 3.49 & 3.44 & 0.20 & 0.04 & 0.51 & 0.11 \\
\hline Protein & 2.95 & 2.95 & 3.00 & 2.93 & 0.05 & 0.50 & 0.24 & 0.28 \\
\hline Lactose & 4.88 & 4.89 & 4.90 & 4.88 & 0.04 & 0.71 & 0.78 & 0.18 \\
\hline $\mathrm{SNF}$ & 8.79 & 8.80 & 8.87 & 8.77 & 0.08 & 0.52 & 0.30 & 0.19 \\
\hline $3.5 \% \mathrm{FCM} / \mathrm{DMI}$ & 1.68 & 1.61 & 1.67 & 1.67 & 0.05 & 0.20 & 0.08 & 0.11 \\
\hline
\end{tabular}

${ }^{1}$ Main effect of corn silage hybrid.

${ }^{2}$ Main effect of ground corn grain endosperm type.

${ }^{3}$ Interaction of corn silage hybrid and ground corn grain endosperm type.

${ }^{4}$ Milk yield not measured during digestibility (d 12 to 14 ) and rumen evacuation (d 19 to 21 ) subperiods.

0.001) and ruminal $\mathrm{pH}$ was greater for vitreous corn grain compared with floury corn grain when fed with the control corn silage (6.23 vs. 6.01 ; Taylor and Allen, 2005a). The increase in milk fat concentration by vitreous corn grain with control corn silage might be because of increased ruminal biohydrogenation and lower flux of trans $\mathrm{C}_{18: 1}$ fatty acids from the rumen with higher ruminal $\mathrm{pH}$. Many studies have shown a negative relationship between milk trans $\mathrm{C}_{18: 1}$ fatty acids and milk fat concentration (Bauman and Griinari, 2003), and higher ruminal $\mathrm{pH}$ might result in more complete biohydrogenation of $\mathrm{C}_{18: 1}$ fatty acids in the rumen. Protein, lactose, and SNF composition of milk were not affected by any treatment. Although a significant main effect of silage $(P<0.005)$ was detected for MUN, differences were small $(<1.5 \mathrm{mg} / \mathrm{dL})$.

Several experiments documented greater milk yield when brown midrib hybrids replaced normal silage, likely from increased DMI (Grant et al., 1995; Oba and Allen, 2000a; Tine et al., 2001). However, there have been inconsistent results regarding ruminal starch degradation and milk production. Plascencia and Zinn (1996) noted a $2.6-\mathrm{kg} / \mathrm{d}$ increase in milk yield when steam-flaked corn replaced dry-rolled corn with a concurrent $1.1-\mathrm{kg}$ increase in DMI. In contrast, replacing corn with steam-rolled barley decreased DMI by $3.2 \mathrm{~kg} /$ $\mathrm{d}$ and milk yield by $4.3 \mathrm{~kg} / \mathrm{d}$ (Overton et al., 1995). Furthermore, changing apparent ruminal nonstructural carbohydrate digestibility by 38.2 units had no effect on DMI or milk production (Callison et al., 2001). Response to increased ruminal starch digestibility affects DMI and milk yield in a similar manner; depression of milk yield generally occurs when DMI is also decreased.
In this experiment, differences in milk production reflect patterns of feeding behavior and DMI. Floury endosperm grain decreased DMI by decreasing meal size when combined with control silage, but did not decrease meal size or DMI when combined with $b m 3$ corn silage likely because fuels from rapid ruminal starch fermentation were used for increased milk yield. The fact that floury grain combined with $b m 3$ corn silage did not depress DMI and increased milk yield seems to contradict conventional wisdom; indeed, we hypothesized that floury grain combined with $\mathrm{bm} 3$ corn silage would depress DMI and possibly milk yield compared with vitreous grain. Understanding how diets interact to affect milk yield has been the goal of ruminant nutritionists for decades. Stage of lactation influences milk yield because of homeorhetic adaptations in hormone secretion and clearance, insulin resistance of tissues, and nutrient demands of various tissues, all of which affect the capacity of the mammary gland to use nutrients for milk. The response to floury grain and $b m 3$ corn silage further emphasizes the need for research to investigate the physiological factors that can influence milk yield and DMI.

\section{Energy Balance and Plasma Metabolites}

An interaction of treatments was detected $(P<0.08)$ for $\mathrm{NE}_{\mathrm{L}}$ intake (Table 5); floury corn grain decreased $\mathrm{NE}_{\mathrm{L}}$ intake by $0.8 \mathrm{Mcal} / \mathrm{d}$ in control silage diets but increased $\mathrm{NE}_{\mathrm{L}}$ intake by $4.3 \mathrm{Mcal} / \mathrm{d}$ in $b m 3$ silage diets. This interaction reflects the changes in DMI observed but also accounts for greater digestibility of corn grain with floury endosperm. Milk $\mathrm{NE}_{\mathrm{L}}(\mathrm{Mcal} / \mathrm{kg}$ ) was in- 
Table 5. Effects of corn grain endosperm type and brown midrib 3 corn silage on energy balance.

\begin{tabular}{|c|c|c|c|c|c|c|c|c|}
\hline & \multicolumn{2}{|c|}{ Control } & \multicolumn{2}{|c|}{ bm3 } & \multirow[b]{2}{*}{ SEM } & \multicolumn{3}{|c|}{$P$} \\
\hline & Floury & Vitreous & Floury & Vitreous & & $\mathrm{S}^{1}$ & $\mathrm{G}^{2}$ & $\mathrm{~S} \times \mathrm{G}^{3}$ \\
\hline BW change, $\mathrm{kg} / 21 \mathrm{~d}$ & 12.7 & 12.3 & 16.9 & 12.1 & 4.4 & 0.62 & 0.51 & 0.58 \\
\hline BCS change, $/ 21 \mathrm{~d}$ & 0.04 & 0.12 & 0.14 & 0.32 & 0.06 & & 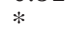 & \\
\hline $\begin{array}{l}\mathrm{NE}_{\mathrm{L}} \text { intake, } \mathrm{Mcal} / \mathrm{d} \\
\text { Milk } \mathrm{NE}_{\mathrm{L}}\end{array}$ & 42.9 & 43.7 & 46.1 & 41.8 & 1.6 & 0.65 & 0.22 & 0.08 \\
\hline Mcal/kg & 0.68 & 0.70 & 0.69 & 0.68 & 0.02 & 0.09 & 0.87 & 0.05 \\
\hline $\mathrm{Mcal} / \mathrm{d}$ & 27.3 & 28.0 & 29.1 & 27.5 & 1.5 & 0.37 & 0.54 & 0.11 \\
\hline $\mathrm{NE}_{\mathrm{L}}$ balance, $\mathrm{Mcal} / \mathrm{d}$ & 5.46 & 5.26 & 6.79 & 3.11 & 1.2 & 0.73 & 0.11 & 0.15 \\
\hline Milk $\mathrm{NE}_{\mathrm{L}}, \%$ of intake & 63.5 & 64.4 & 62.9 & 68.5 & 2.6 & 0.36 & 0.10 & 0.22 \\
\hline
\end{tabular}

${ }^{1}$ Main effect of corn silage hybrid.

${ }^{2}$ Main effect of ground corn grain endosperm type.

${ }^{3}$ Interaction of corn silage hybrid and ground corn grain endosperm type.

*Significant $(P<0.15)$ period $\times$ treatment interaction.

creased for vitreous vs. floury corn grain combined with control silage but was decreased when combined with bm3 corn silage (interaction $P<0.05$ ) because of the similar treatment effects on milk fat yield. A tendency for an interaction of treatments was detected for $\mathrm{NE}_{\mathrm{L}}$ balance $(P<0.15)$. Energy balance was similar between endosperm types in control silage diets but was greater for floury grain than vitreous within $b m 3$ silage diets.

Vitreous endosperm corn grain tended to increase partitioning of energy toward milk compared with floury endosperm grain $(P<0.10$; Table 5$)$. Plasma insulin:glucagon ratio tended to be higher for cows consuming vitreous grain diets $(P<0.07$; Table 6$)$ because vitreous grain numerically increased plasma insulin concentration. Greater plasma insulin concentration might be expected to increase energy partitioned toward tissue retention and not milk, but other factors influence energy partitioning, including substrate availability and secretion of other hormones. Additionally, these samples taken every $3 \mathrm{~h}$ over a 24 -h period represent basal hormone profiles but metabolic hormones act in a much shorter time frame, and pulsatility of insulin and glucagon plays a significant role in whether glucose is used toward tissue energy retention vs. milk production. Because more frequent sampling is required to identify insulin and glucagon peaks and nadirs, we do not know how endosperm type affects temporal concentration patterns of these hormones. More research is needed to examine the interactions of starch and fiber digestibility on hormone pulsatility and energy balance.

\section{CONCLUSIONS}

Corn grain endosperm type and $b m 3$ mutation in corn silage interact to affect DMI; floury endosperm grain decreased meal length and size in control silage diets but increased meal length and size in $b m 3$ silage diets. Total DMI was not reduced in diets containing vitreous corn grain and bm3 corn silage because bm3 silage tended to increase meal frequency per day compared with control corn silage. Ruminal pool sizes reflected treatment effects on DMI, indicating that DMI was probably not limited by physical fill. Differences in feed-

Table 6. Effects of corn grain endosperm type and brown midrib 3 corn silage on plasma metabolite and hormone concentrations.

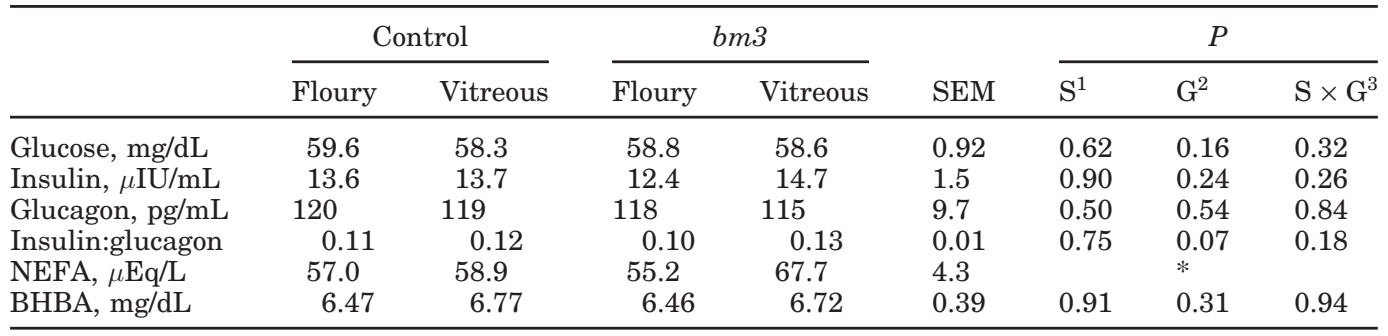

${ }^{1}$ Main effect of corn silage hybrid.

${ }^{2}$ Main effect of ground corn grain endosperm type.

${ }^{3}$ Interaction of corn silage hybrid and ground corn grain endosperm type.

*Significant $(P<0.15)$ period $\times$ treatment interaction. 
ing behavior could have been caused by a number of regulatory factors including, but not limited to, temporal supply of nutrients, oxidation of metabolic fuels, gut peptides, and metabolic hormone profiles. Changing diet fermentability affects milk production primarily by affecting DMI. Additionally, production responses to $b m 3$ corn silage are dependent on grain source. Starch and fiber fermentability can interact to affect feeding patterns and productivity.

\section{ACKNOWLEDGMENTS}

We wish to acknowledge Purina Mills, Inc., and Syngenta Seeds, Inc., for their financial support of this research. The authors thank N. K. Ames for performing duodenal and ruminal cannulations, and thank D. G. Main, Y. Ying, R. A. Longuski, C. S. Mooney, J. A. Voelker, K. J. Harvatine, B. J. Bradford, and R. E. Kreft for technical assistance and support.

\section{REFERENCES}

Allen, M. S. 2000. Effects of diet on short-term regulation of feed intake by lactating dairy cattle. J. Dairy Sci. 83:1598-1624.

Bauman, D. E., and J. M. Griinari. 2003. Nutritional regulation of milk fat synthesis. Annu. Rev. Nutr. 23:203-227.

Beauchemin, K. A., T. A. McAllister, Y. Dong, B. I. Farr, and K. J. Cheng. 1994. Effects of mastication on digestion of whole cereal grains by cattle. J. Anim. Sci. 72:236-246.

Callison, S. L., J. L. Firkins, M. L. Eastridge, and B. L. Hull. 2001. Site of nutrient digestion by dairy cows fed corn of different particle sizes or steam-rolled. J. Dairy Sci. 84:1458-1467.

Cherney, J. H., D. J. R. Cherney, D. E. Akin, and J. D. Axtell. 1991. Potential of brown-midrib, low-lignin mutants for improving forage quality. Adv. Agron. 46:157-198.

Dado, R. G., and M. S. Allen. 1993. Continuous computer acquisition of feed and water intake, chewing reticular motility, and ruminal pH of cattle. J. Dairy Sci. 76:1589-1600.

Grant, R. J., S. G. Haddad, K. J. Moore, and J. F. Pedersen. 1995. Brown midrib sorghum silage for midlactation dairy cows. J. Dairy Sci. 78:1970-1980.

Havel, P. J. 2001. Peripheral signals conveying metabolic information to the brain: Short-term and long-term regulation of food intake and energy homeostasis. Exp. Biol. Med. 226:963-977.

Kotarski, S. F., R. D. Waniska, and K. K. Thurn. 1992. Starch hydrolysis by the ruminal microflora. J. Nutr. 122:178-190.

Krause, K. M., D. K. Combs, and K. A. Beauchemin. 2003. Effects of increasing levels of refined cornstarch in the diet of lactating dairy cows on performance and ruminal pH. J. Dairy Sci. 86:1341-1353.

Langhans, W. 1996. Role of the liver in the metabolic control of eating: What we know-and what we do not know. Neurosci. Biobehav. Rev. 20:145-153.

Lavin, J. H., G. A. Wittert, J. Andrews, B. Yeap, J. M. Wishart, H. A. Morris, J. E. Morley, M. Horowitz, and N. W. Read. 1998. Interaction of insulin, glucagon-like peptide 1 , gastric inhibitory polypeptide, and appetite in response to intraduodenal carbohydrate. Am. J. Clin. Nutr. 68:591-598.

National Research Council. 1989. Nutrient Requirements of Dairy Cattle. 6th rev. ed. National Academy Press, Washington, DC.

National Research Council. 2001. Nutrient Requirements of Dairy Cattle. 7th rev. ed. National Academy Press, Washington, DC.

Nocek, J. E., and S. Tamminga. 1991. Site of digestion of starch in the gastrointestinal tract of dairy cows and its effect on milk yield and composition. J. Dairy Sci. 74:3598-3629.

Oba, M., and M. S. Allen. 1999. Evaluation of the importance of the digestibility of neutral detergent fiber from forage: Effects on dry matter intake and milk yield of dairy cows. J. Dairy Sci. 82:589-596.

Oba, M., and M. S. Allen. 2000a. Effects of brown midrib 3 mutation in corn silage on productivity of dairy cows fed two concentrations of dietary neutral detergent fiber: 1 . Feeding behavior and nutrient utilization. J. Dairy Sci. 83:1333-1341.

Oba, M., and M. S. Allen. 2000b. Effects of brown midrib 3 mutation in corn silage on productivity of dairy cows fed two concentrations of dietary neutral detergent fiber: 2 . Chewing activities. J. Dairy Sci. 83:1342-1349.

Oba, M., and M. S. Allen. 2003a. Effects of corn grain conservation method on feeding behavior and productivity of lactating dairy cows at two dietary starch concentrations. J. Dairy Sci. 86:174-183.

Oba, M., and M. S. Allen. 2003b. Extent of hypophagia caused by propionate infusion is related to plasma glucose concentration in lactating dairy cows. J. Nutr. 133:1105-1112.

Overton, T. R., M. R. Cameron, J. P. Elliot, J. H. Clark, and D. R. Nelson. 1995. Ruminal fermentation and passage of nutrients to the duodenum of lactating cows fed mixtures of corn and barley. J. Dairy Sci. 78:1981-1998.

Philippeau, C., F. Le Deschault de Monredon, and B. Michalet-Doreau. 1999a. Relationship between ruminal starch degradation and the physical characteristics of corn grain. J. Anim. Sci. 77:238-243.

Philippeau, C., C. Martin, and B. Michalet-Doreau. 1999b. Influence of grain source on ruminal characteristics and rate, site, and extent of digestion in beef steers. J. Anim. Sci. 77:1587-1596.

Philippeau, C., and B. Michalet-Doreau. 1997. Influence of genotype and stage of maturity of maize on rate of ruminal starch degradation. Anim. Feed Sci. Technol. 68:25-35.

Plascencia, A., and R. A. Zinn. 1996. Influence of flake density on the feeding value of steam-processed corn in diets for lactating cows. J. Anim. Sci. 74:310-316.

Taylor, C. C., and M. S. Allen. 2005a. Corn grain endosperm type and brown midrib 3 corn silage: ruminal fermentation and $\mathrm{N}$ partitioning in lactating cows. J. Dairy Sci. 88:1434-1442.

Taylor, C. C., and M. S. Allen. 2005b. Corn grain endosperm type and brown midrib 3 corn silage: Site of digestion and ruminal digestion kinetics in lactating cows. J. Dairy Sci. 88:1413-1424.

Tine, M. A., K. R. McLeod, R. A. Erdman, and R. L. Baldwin, VI. 2001. Effects of brown midrib corn silage on the energy balance of dairy cattle. J. Dairy Sci. 84:885-895.

Watford, M., and A. G. Goodridge. 2000. Regulation of fuel utilization. Pages 384-401 in Biochemical and Physical Aspects of Human Nutrition. M. H. Stipanuk, ed. W. B. Saunders Co., Philadelphia, PA.

Wildman, E. E., G. M. Jones, P. E. Wagner, R. L. Boman, H. F. Troutt, Jr., and T. N. Lesch. 1982. A dairy cow body condition scoring system and its relationship to selected production characteristics. J. Dairy Sci. 65:495-501. 